\title{
Smashing Birds in the Wilderness: British Racial and Cultural Integration from Insider and Outsider Perspectives
}

\author{
Karen Sands-O'Connor
}

$\mathrm{T}$ The idea of Britain as a multicultural society is just beginning to be widely recognized in literature for children and young adults. Although cities such as London and Birmingham have had racially-mixed populations in increasing proportions since at least the end of World War II ${ }^{1}$, children's and young adult literature has largely ignored the change until recently, maintaining a focus on traditional (imperial-related) themes and characters written by white authors. Even as British society faces up to its multiracial reality, literature for young people has mirrored the ambivalence felt by both traditional and recent citizens about cultural and racial integration. Young adult literature in particular, due to its often 'problem-focused' nature, has begun to address racism more and more often within the last ten years. However, as novels such as Kate Elizabeth Ernest's Birds in the Wilderness (1995), Robert Swindells's Smash! (1997), and Malorie Blackman's Noughts and Crosses (2001) show, perspectives on racial issues vary considerably.

Following the end of World War II, the British nation was in a state of change. Britain was facing an influx of immigrants, both in the form of displaced persons (DPs) from Europe and colonial migrants, particularly from the West Indies and Asia. Although initially these immigrants had been a welcome relief to the post-war labour shortages (Kay 1995, p.155; Anwar 1995,p.274), racial considerations soon came to the forefront in these discussions. Kay notes that 'in the case of the UK the preferred source of foreign labour was west Europe "whose traditions and social background were more nearly equal to our own" [Kay and Miles 1992, p.47]. Only when this was not forthcoming were DPs from eastern Europe considered. Furthermore Jewish DPs were "routinely excluded" from recruitment [Cesarini 1992:4-5]' (Kay 1995, p.156). Reaction to West Indian migration was even stronger, even though these newcomers were British subjects; by 1954, Conservative members of Parliament were calling for restriction of black immigration ${ }^{2}$. Shyllon notes that 'The first Commonwealth Immigration Act was passed in 1962, a second in 1968 and a third in 1971, each Act having the intended effect of further severely restricting entry' (Shyllon 1992, p.215). Although Parliament also passed Race Relations Acts in 1965, 1968 and 1976, these were generally seen to be less than effective (Patterson 1969, p.82; Kushnick 1971, p.234); certainly, they did not prevent racial tensions from exploding into riots and anti-black reaction, such as Enoch Powell's 'River of Blood' speech ${ }^{3}$, given six months before passage of the 1968 act. Reactionary attitudes toward black migration into Britain had a serious impact on the nation's legislation and popular press (Glass 1961, pp.147-211; Anwar 1995, p.276; Kushnick 1971, pp.233-268; Shyllon 1992, pp.214-219), and gave rise to a movement to 'keep Britain white' that continues even today (Ansell 1997, pp.168-169). The British National Party, founded by Enoch Powell, has even won a larger share of parliamentary seats in the recent past, as racial tensions in places such as Oldham, Burnley, and Stoke-on-Trent re-emphasize the lack of unity between citizens of different races. In fact, current BNP leader, Nick Griffin, has vowed recently to 'reverse the tide of immigration. The ultimate goal is an all-white Britain' (2003, p.2). The Home Office report that followed the racial disturbances in Oldham and Burnley in 2001 tried to minimise the focus on race as a cause, suggesting instead that it was 'the lack of a strong civic identity or shared social values' (2001, p.12) that played the key role in the difficulties. Even those in favor of ' a more inclusive country in which everyone can realise their full potential' (Blair 2003, p. 5), as Tony Blair argues in the government report on 'Ethnic Minorities and the Labour Market', suggest that the way will be difficult. Rather than welcoming difference and diversity, this and other government policy seems to plead for mere tolerance from the majority white society: '[T]hough it is nearly 40 years since the first Race Relations Act', Blair writes, 'it is clear that racial discrimination in the labour market still persists. This problem needs to be tackled in much more sophisticated ways that address underlying causes and gain the support of a larger number of employers' (Blair 2003, p.5). For more than forty years, race has been an issue for all British citizens.

This is a point emphasized by writers such as Paul White, who argues that 'Transformations also occur in the lives of all those involved; not just the migrants themselves but also those who directly come into contact with them and those who, indirectly, are affected by social, political and economic changes induced by migration' (White 1995, p.1). But while many areas of British culture for adults have addressed the issue of cultural integration, including television (Steptoe and Son), film (Bhaji on the Beach), and the popular press, attempts to produce more children's literature about ethnic minorities have often ended in dismal failure. Kim Reynolds, in 'Publishing practices 
and the practices of publishing' (1999), tells of a contest by one of the publishing houses to find 'an exciting new voice from any of Britain's ethnic minorities' (p.35) in the 1970 s that ended with a middle-class white male winning the prize. The contest was never repeated, and children's literature remained largely silent at worst or indirect at best concerning race until very recently. This extends to all three major children's target audiences: readers of picture books, young readers, and young adults although each has texts which deal with the representation of blacks in different ways.

Children's picture books in Britain have, since the 1980s, begun depicting a multiracial society, but with few exceptions these books show children eager to fit into traditional British society. The plot of Mary Hoffman's lauded and popular 1991 picturebook Amazing Grace, for example, is about a young Black Briton who wants to play Peter Pan in her class play. Many picture books leave the issue of race entirely out of the verbal text, allowing the illustrations to do the work of depicting the multicultural society. According to 'Why Are People Different?: Multiracial families in picture books and the dialogue of difference,' British picture books often 'have possible indications of racial backgrounds - Wait and See (1988) has a map of Jamaica on the wall of Jo's house- - [but] the plots remain apolitical'(Sands-O'Connor 2001,p.422). This strategy has worked well for picture book authors, who can thus present a non-threatening view of multicultural Britain.

However, what has worked for British picture books becomes more problematic in books for older readers. British fiction for young readers tends to display minority characters positively, but equally marked out as different. One example is the character of Clipper Young, in Gillian Cross's Save Our School series (1981-1991). Clipper should be the most popular girl in the class, as she is the head of the class in games (much like Harry Potter is, and other heroes of school stories). However, she is instead part of an outsider group that includes a fat kid and the class brain. Both of Clipper's friends are white boys, and are described as such in the text. Spag (the class brain) has 'skinny white legs' (Swimathon p.113), and fat Barny Gobbo's face turns red with exercise (The Mintyglo Kid p.96) or rage (The Mintyglo Kid p.105). Clipper, on the other hand, is never physically described at all in the last three books, except to point out that she is athletic. Certainly, Cross's books rely primarily on action rather than description, but Clipper is less fleshed-out than either of her two friends; in addition to less physical description, her family is rarely mentioned and never described either, in contrast to both Spag's and Barny's parents.

This vagueness about Clipper's physical characteristics and family background seems odd, especially as Clipper is described by Keith Barker as, 'Gillian Cross's own favourite character' (Barker 1992, p.8). But the illustrations suggest a reason for Cross's relative lack of description of the girl athlete; Clipper is black. This is not an inclusion by the illustrators (both Gareth Floyd and Philippe Dupasquier portray Clipper as a thin black girl with short curly hair) but a deliberate attempt by Cross at multiculturalism. The first book, Save Our School (1981) does include a passing reference to Clipper's skin color, but it is when Spag and Barny are regarding her from a distance; the text writes of Clipper's 'small brown figure' (1981 p.87). However, this comes after several other descriptions that leave out her skin color. At one point, Clipper, 'bared her white teeth' (1981 p.20); at another, Spag comments that Clipper is 'ugly' (1981 p.79). Thus, the only book in the series that does describe Clipper's skin color also portrays her in a highly negative light physically, making the description of skin color extremely problematic. Cross argues that writers from her generation paint a 'communal picture of modern Britain [that] is anachronistic. It doesn't reflect the multicultural mix of our society...Certainly I try-lots of people try - to remember that things are different now, but it's tricky' ('Twenty Things I Don't Believe About Children's Books' 1991, p.39). Clipper is in fact textually exactly the same as her white friends, and a reprinted edition could conceivably — due to Cross's nearly complete omission of race in the written text-illustrate Clipper as a white child. What works for picture books, where author and illustrator become part of a combined vision, is not as simple in texts for older readers. However, for both picture books and young reader books, the goal of multiracial books has seemed to be mere inclusion of race, and not problem-solving (or, in many cases, even the addressing of the problem) about racism.

Young adult literature, in contrast, is often focused on problem situations, so it is not surprising that this genre has been the 
most direct at addressing racism in British literature for young people. Peter Hollindale suggests that writers for adolescents produce, 'challenging, disturbing, and often pessimistic visions of the modern human plight' $(1995, \mathrm{p} .88)$ because this age group of readers 'may have a vital part to play' (p.88) in the resolution of these problems. Indeed, the growing availability of books concerned with racism mirrors what Susan Hancock et al call, 'a need [for ethnic minority readers] to be prepared for aggressive social situations such as racism and bullying' (Hancock 1999, p.20). But although more and more novels make racism their central issue, the conclusions these books have reached have differed. Their reception has also differed, indicating that British culture is still not prepared to deal with the problematic and complex realities of racism and racial integration.

During the decades when Britain's population was undergoing the highest levels of change, the 1950s and 1960s, fiction for older children and young adults remained steadfastly uniform in their depiction of white characters only. Minority characters who appeared were generally part of the vast and vague 'rest of the world,' and were often being saved by the British (white) characters. In Susan Cooper's Silver on the Tree (1977), for example, the main (white, English) characters are at the head of a train leading to the final rising of the light against the dark. One of the boys, Simon, tells his sister, '... The train's pretty full already, as far as I went. With the most peculiar mix of people, all in different clothes. All kinds of colours and shapes. It's like the United Nations' (Cooper 1984, p.755). John Christopher's Tripods trilogy (1967-1968) also ends with a United Nations of sorts - one in chaos because of 'petty bickering' (Christopher 1968, p.216) between the nations. In both cases, nonwhite people all originate outside the borders of England. Citizens of England-and saviours of the planet-are white.

Few novels of the time provide much depth for nonwhite characters who do appear. One exception is Penelope Lively's The House in Norham Gardens (1974), where a young white girl, Clare, gets to know her aunt's black lodger, John. But even though Lively gives John more direction to develop in the novel, he is still an outsider to Britain, a student from Uganda. Clare does not expect him to make Norham Gardens a permanent home (Lively 1974, p.153). She does not have to help him integrate or accept him as a full and contributing member to her culture.
In the 1990s, however, British young adult novels began making race a central issue. By this time, nonwhite communities were firmly established in many British cities and towns, and much of Britain's black population were second or even third generation citizens ${ }^{4}$. Blacks had even established some of their own traditions as a part of British culture. Curry had replaced fish and chips as the nation's favourite takeaway meal. The Notting Hill Carnival was a regular feature of August Bank Holiday, enjoyed by all races though still run by the British West Indian community. However, racial tensions had not ceased in the nation, and several high profile cases, particularly the death of Stephen Lawrence, a young black Briton, in April 1993, kept a spotlight on the issue.

Stephen Lawrence's death shocked the entire nation. While waiting for a bus, he was attacked and murdered by five or six white youths for apparently no reason other than his race. The official inquiry into his death comments, 'Stephen Lawrence's murder was simply and solely and unequivocally motivated by racism. It was the deepest tragedy for his family. It was an affront to society, and especially to the local black community in Greenwich' (MacPherson 1999, section 1.11). Police bungled the investigations into his death, and the murderers were never brought to justice. However, Lawrence's murder brought racism to the front pages of the newspapers for the first time in years, and opened up the topic for discussion by the general public.

Not coincidentally, at about this same time more books about race were being published in the United Kingdom. As James Proctor notes in Writing Black Britain, 'the black British past is... a politically loaded, politically active site of remembrance from which we all must learn' (Proctor 2000, p.196), especially since the death of Stephen Lawrence. For young adults, this meant the publishing of books that dealt specifically with the topic of racism. Two books, both published by major British publishers, showcase different viewpoints on the subject. Kate Elizabeth Ernest's Birds in the Wilderness (1995), is an historical novel written from the perspective of a young black girl recently arrived in Britain from Jamaica during the 1960s. Robert Swindells's Smash! (1997) tells the story of a white boy whose best friend is Pakistani, yet who nonetheless gets mixed up with racist hate groups. Athird book, Malorie Blackman's Noughts and Crosses (2001), and its sequel, An Eye for an Eye (2003), imagine a world where blacks are in charge and whites 
are oppressed. The different perspectives of the authors of these novels result in vastly different conclusions, but all suggest that both blacks and whites in Britain are doubtful about racial integration and harmony.

Birds in the Wilderness is actually a sequel to Ernest's 1993 novel, Hope Leaves Jamaica; however, Birds is the only one of the two that takes place in England. Although Ernest's original novel has a sense of foreboding toward the young main character's eventual departure for England, the reason for this negativity is unclear. Hope comments that, 'a new dread took hold of us: England!' (Ernest 1993, p.122), but she seems more upset about leaving her cherished grandparents than actually going to a new country. In the foreword to Birds in the Wilderness, however, Ernest makes clear that the uncertain feeling the children had was not unfounded: 'The transition from a West Indian childhood to a life in a different environment was a culture shock' (Ernest 1995, p.6). Hope not only has to deal with a different physical environment of cold and fog, but a different social environment as well-one where racism was a normal everyday part of life. Sophie Mackay notes that novels of adolescence and novels of migration are related because of the struggles both endure: 'Migration raises issues about the difficulties of belonging to two cultures, which can be compared to the difficulties all adolescents experience as a result of being in between the cultures of childhood and adulthood' (Mackay 2001, p.66). This possibly explains why Birds in the Wilderness is fraught with tension, whereas the earlier book, set in childhood, is not. It is also useful to compare Jamila Gavin's childhood memoir, Out of India (1997, reprinted in 2002), in which the Anglo-Indian writer moves back and forth between England and India without reporting much trauma; in fact, she is able to write at the conclusion of the memoir, 'England feeds me as much as India did...I am truly a child of both countries and both cultures, and could not deny either of them' (Gavin 1997, p.110). Childhood migration is reported in Gavin's account as an adventure; adolescent migration according to Ernest involved fear, confusion, loneliness and racism.

Hope experiences her first incidence of racism before she even enters her new English home. The scrap man, whom Hope describes as needing 'a good shave, a haircut and a bath' (Ernest 1995, p.10), comments that he doesn't un- derstand 'why you coloured people keep coming' (p.10), before spitting on the ground before them. Although Hope's father puts it down to bad manners, Hope soon learns that her world is filled with white people who share similar attitudes. Her father sends her to the Catholic school so that Hope does not get mixed up 'with girls who smoked, swore in public, behaved like rowdies on the buses' (p.18), but her schoolmates prove to be no better behaved. They insinuate that she is a monkey (pp.31,33), and spit on her (p.34) during her first day at school. Ernest makes it clear through her narration that the white girls' behaviour is sanctioned by their parents; one girl comments, 'My dad says coloured people come from Africa; they like swinging through the trees like Tarzan' (p.31) and another girl's parents are planning to emigrate to Australia because ' $\mathrm{t}] \mathrm{h}$ here are no coloured people there' (p.31). Even well-meaning adults add to the problem. The geography teacher, Sister Agnes, tells students about starvation in Africa, suggesting, 'Wemust pray for these people... They need grains to plant; they need to be educated' (p.29). All eyes in the room turn on Hope. Even though Sister Agnes assures the class that the Jamaicans came to England because workers were needed, she cannot dispel the connection between Hope and the Africans, making Hope feel acute shame. Hope learns that in England, shame about her colour is a way of life. Ernest, as author, demonstrates here that being well-intentioned about racial harmony is not enough to bring that harmony about.

Things hardly improve for Hope over the course of the novel. The racial slurs are endemic, and her teachers find her strangely distracted at school, and give her low marks. Her family situation also declines, as her father, frustrated by the racism he has to face, becomes abusive. Birds in the Wilderness ends tensely, uncertainly. Hope's mother gets a promotion, which only depresses Hope's father all the more. "'Boys, black women have all the luck in this country, unlike us," Father said. "We could work from now till Thy kingdom come and we still wouldn't get promotion.", (pp.148-149). Again, Ernest is suggesting that by focusing on race - whether it is in the well — meaning way of Sister Agnes, or the bitter accusations of Hope's father-success, either individual or societal, will never be achieved. Nor does Ernest supply an alternative. Hope's father decides to accompany his brother's coffin back to Jamaica, and Hope suspects he will not return. The novel ends with Hope's musing: 'A feeling of uneasiness washed over me and I said 
to myself, "Will we still be together this time next year?", (p.158). Birds in the Wilderness is a novel that chronicles not only the immediate effects of racism but also its longterm consequences to family and society.

Robert Swindells's Smash! is a more dramatic story set in contemporary Britain. A white boy, Stephen Crowley, and a British-born Pakistani, Ashraf Khan, are best friends. When white youths attack a girl from a Pakistani neighborhood, however, the boys end up on different sides of a town disagreement. Stephen even becomes involved with a racist organization called Blackout, that wants to rid the town of ". . . people next door playing bongos all night and doing their business in the garden"' (Swindells 1997, p.62). Although Smash! tells the story through multiple focalisers, most of the narration is given over to Stephen's thoughts and feelings. This is perhaps due to the fact that Swindells is white. In any case, the situation in the town deteriorates into racial brawls, and these are only stopped when a young white reporter, Jennifer Most, breaks the story in a local paper of the high-level people involved and the deaths that are resulting.

Smash! suggests similar ideas to Birds in the Wilderness. Both books argue that racism is something young people learn from surrounding adults, and both suggest it can cause harm to families and communities. But whereas Birds offers little hope for an uncertain future, Smash! posits a different conclusion. In a much more optimistic ending, Stephen and Ashraf become friends again, Steve starts dating Ashraf's sister Abi, and the community builds a Millennium Centre that brings all groups together. The boys make friends in the hospital, where they are coincidentally placed next to each other to heal after they are both injured in a racial brawl. The narrator explains their restarting friendship by commenting, 'Ashraf decided it had something to do with the fact that everybody was in the same boat, and that when you sleep two metres away from somebody for a week, you can't go on believing they are a member of an alien species' (p.167). The 'real' bad characters - adult organizers of racist groups and racist property developers - die, go to prison, or are put in insane asylums. The Bennett Qureshi Development, jointly financed by the city's richest white and black citizens, becomes the 'gateway to the third millennium' (p.184). Presumably, this will be a millennium without racism, as this novel ends with Stephen and his sister Colleen hugging Ashraf and his sister Abi. Swindells relies both on human willingness to communicate across boundaries of whatever kind as well as a belief in the positive influence of the justice system to create his millennium community.

This upbeat ending contrasts strongly with the current reality in Britain, where newspapers routinely report incidents of racism. Rather than happy endings of interracial harmony and fitting punishments for racists, newspaper articles report such events as 'An Asian father of three was kicked to death in a busy high street when he objected to racist remarks' (2003 p.5). In this particular incident, despite the 'busy' street, only one person - also described as Asian - attempted to intervene. The two white attackers were released on bail pending trial. Media emphasis on racial disharmony results from a variety of causes, not the least of which is the market-driven desire to sell more papers, as well as the more altruistic aim of pressuring for governmental reform. However, by highlighting the separateness of different ethnic groups within Britain, these reports reinforce the notion that communication among groups is difficult if not impossible, and that mere tolerance of other people would be an acceptable solution. Swindells makes a clear attempt in his novel to offer an alternative vision of race relations; he himself has argued that he makes 'no attempt to be even-handed' (Young Writers website) with his solutions. Smash! can be seen in the context of British society as a hopeful vision of a possible future where different groups unite to form a single, peaceful society; it can also be seen as painfully naïve in its attempt to portray racial harmony that is all-embracing.

Smash!'s' ending also highlights a key difference between the two authors and their vision of British racism. Ernest's Birds holds out little hope for the future, and ends with an unhappy sense of uncertainty. Swindells'book, on the other hand, ends with such an unrealistic harmony that it jars against the earlier scenes of racial tension and brutal violence. Both endings suggest that, at least for the immediate future, racism will be a way of life for black Britons, and that it is not until white people want to accept and champion others into the UK that anything will change.

But perhaps even this will not suffice. Malorie Blackman, in Noughts and Crosses, offers a third perspective on the issue of race in Britain. Blackman, born in London of West Indian parents, is both black and British. Her 
novel re-presents this outsider-yet-insider point of view by being neither an historical fiction nor a contemporary one. Noughts and Crosses is a fantasy set in an alternative world where black-skinned people have and have always had power, and white-skinned people are and have always been oppressed (were, in fact, once enslaved).

The Romeo-and-Juliet plot of the book-black daughter (Sephy) of prominent politician has a romantic relationship with the white son (Callum) of her family's former maid-holds few surprises. In fact, it seems to be one of Blackman's aims to show that power always corrupts, no matter who holds it. Blacks, or Crosses, hold the best jobs, receive the best education, and drink away any guilt feelings they might have about their place in society. Whites, or noughts, endure racial slurs, have few to no opportunities, and have to decide between self-elimination (through suicide or planned invisibility within the society) and elimination of the Crosses (via the Liberation Militia, a terrorist organization).

Sephy and Callum's relationship, like the relationship between Steve and Ashraf in Smash!, is unstable due to the cultural dominance of one race over another. Callum eventually joins the Liberation Militia and plays a role in kidnapping Sephy for the group. Although Sephy tries to convince Callum that she is on his side by arguing that at her new school, "'I became involved in protests and debates and sit-ins"' (Blackman 2001, p.363) to improve the plight of whites, this information only enrages Callum. "'I'm sick of your charity and your handouts... You're just like all the others"' (p.363), he tells her. The novel seems destined to end like Birds in the Wilderness, with tension and uncertainty about the future.

Blackman, however, manufactures a conclusion that falls in between Ernest's and Swindells' novels - a conclusion that is in some ways more depressing than either. Despite Callum's attempts to dehumanize Sephy, he finds himself unable to resist her sexually, and they make love 'consensually' while he is her captor (and soon after he has cut her with a knife). As if the kidnapping had all been just a silly misunderstanding, he then helps her escape and she helps him by revealing the identity of a double agent in their Liberation Militia.

Unfortunately, this is the last time Sephy and Callum speak to each other directly. Callum is arrested, tried, and sentenced to death for Sephy's kidnap. Blackman ameliorates this grim event by having Sephy and Callum declare their love for each other at the hanging. Sephy goes on to give birth to Callum's child and names it after him; the last page consists of the birth announcement. Nonetheless, this hopeful-seeming ending is negated by the events and emotions that immediately precede it. Like Swindells, Blackman ignores all the pressing racial issues she has introduced in order to provide some hope for the future.

Britain has become, since the end of World War II, an irreversibly multicultural society, full of tension and uncertainty between different ethnic groups. However, publishing for young adults continues to preference optimistic and hopeful visions of British racial harmony over books that mirror cultural reality. In contrast to novels and picture books for younger readers, which have taken an overall integrative and positive if nonconfrontational approach, young adult literature has attempted to commit to a discussion of racism. Both plots and characters address racial issues in young adult novels; but the plots, filled with violence and sexual tension, and reliance on simply-achieved happy endings, often overshadow any potential focus on character insight or growth. It seems to me no accident that Birds in the Wilderness, the only one of these young adult novels without a happy ending, is out of print and has been since 1997, while Noughts and Crosses and Smash! are both still in print and Noughts and Crosses won the Lancashire Children's Book Award and has one sequel already published and another in production. As long as readers - from whatever perspective - continue to prefer eroticized and sensationalized visions of race with quickly and easily achieved happy endings, the birds crying out in the wilderness for recognition, acceptance and equality will continue to be smashed.

\section{END NOTES}

1. Although the Black population of Britain goes back at least three hundred years, James Proctor is right to posit 1948 as a key turning point in the history of Black Britain. See his introduction in Writing Black Britain (Proctor 2000) for more on this.

2. Throughout this paper, I will be using the definition of Black provided by the UK's Institute of Race Rela- 
tions. The IRR uses the term 'Black' to 'refer to nonwhite groups - with heritages in Asia, Africa and the Caribbean-who share a common experience of British racism' (website http://www.irr.org.uk, 'Statistics and Definitions'.

3. Enoch Powell, a British Member of Parliament in the 1960s and founder of the anti-immigration British National Party, spoke against the Race Relations Bill of 1968. Powell argued, 'Now we are seeing the growth of positive forces acting against integration, of vested interests in the preservation and sharpening of racial and religious differences, with a view to the exercise of actual domination, first over fellow-immigrants and then over the rest of the population' (Powell, p.5) and, 'As I look ahead, I am filled with foreboding; like the Roman, I seem to see "the River Tiber foaming with much blood"' (p.5).

4. Recent studies suggest that ethnic minorities not only make up the majority of certain boroughs and electoral wards in London and other major cities, but have also begun moving to the suburbs. As Deborah Phillips puts it, 'there are more ethnic minorities moving out to areas where they didn't used to live' (sic, qtd in The Times 4 August 2003, p.6).

\section{REFERENCES}

Ansell, Amy Elizabeth (1997) New Right, New Racism: Race and Reaction in the United States and Britain. New York, New York University Press.

Anwar, Muhammed (1995) “'New Commonwealth" Migration to the UK', in Cohen, Robin (ed) The Cambridge Survey of World Migration. Cambridge, England, Cambridge University Press, pp. 274-278.

Barker, Keith (1992) Gillian Cross. Swindon, England, School Library Association.

Blackman, Malorie (2001) Noughts and Crosses. London, Doubleday.

Blackman, Malorie (2003) An Eye for an Eye. London, Doubleday.

Blair, Tony (2003) 'Prime Minister's Foreword.' Ethnic Minorities and the Labour Market.
London, Cabinet Report.

'BNP thugs triumph in the local elections.' International Express 6 May 2003, p.2.

Browne, Anthony (2003) 'Ethnic minorities spread out from cities to suburbs', The Times 4 August, p. 6

Christopher, John (1968) The Pool of Fire. New York, Collier.

Cooper, Susan (1984) The Dark is Rising sequence. London, Puffin.

Cross, Gillian (1981) Save Our School. London, Mammoth.

Cross, Gillian (1983) The Mintyglo Kid. London, Mammoth.

Cross, Gillian (1986) Swimathon! London, Methuen.

Cross, Gillian (1991) Gobbo the Great. London, Mammoth.

Cross, Gillian (1991) 'Twenty things I don't believe about children's books', School Librarian 39, 2: 44-46.

Ernest, Kate Elizabeth (1993) Hope Leaves Jamaica. London, Methuen.

Ernest, Kate Elizabeth (1995) Birds in the Wilderness. London, Methuen.

Gavin, Jamila (1997) Out of India. London, Hodder.

Glass, Ruth (1961) London's Newcomers: The West Indian Migrants. Cambridge, Massachusetts, Harvard University Press.

Griffin, Nick (2002) International Express, 6 May, p.2.

Hancock, Susan with Pat Pinsent and Ishtla Singh (1999) Young People's Reading at the End of the Century: Focus on Ethnic Minority Pupils. London, British Library Board.

Hollindale, Peter (1995) 'The adolescent novel of ideas', Children's Literature in Education 26, 1: 83-95.

Home Office Report (2001) Building Cohesive Communities: A Report of the Ministerial 
Group on Public Order and Community Cohesion. London, Home Office.

Kay, Diana (1995) 'The resettlement of displaced persons in Europe, 1946-1951', in Cohen, Robin (ed) The Cambridge Survey of World Migration. Cambridge, England, Cambridge University Press, pp. 154-158.

'Kicked to death in front of shoppers' (2003) International Express, Tuesday 1 July, p. 5

Kushnick, Louis (1971) 'British antidiscrimination legislation', in Simon Abbott (ed) The Prevention of Racial Discrimination in Britain. London, Oxford University Press, pp. 233-268.

Lively, Penelope (1974) The House in Norham Gardens. London, Heinemann.

Mackay, Sophie (2001) 'Itinerant identities: Migration, displacement and adolescence', in The Big Issues: Representations of Socially Marginalized Groups and Individuals in Children's Literature, Past and Present. London, National Centre for Research in Children's Literature, pp. 64-72.

MacPherson, Sir William of Cluny (1999) The Stephen Lawrence Inquiry. Advised by Tom Cook, the Right Reverend John Sentamu and Dr. Richard Stone. Presented to Parliament by the Secretary of State for the Home Department by Command of Her Majesty.

Patterson, Sheila (1969) Immigration and Race Relations in Britain, 1960-1967. London, Oxford University Press.

Powell, Enoch. (1968) 'River of Blood Speech'. Speech made to the British Parliament, April. The Sterling Times. http://www.sterlingtimes. org/text_rivers_of_blood.htm

Proctor, James (ed) (2000) Writing Black Britain 1948-1998: An Interdisciplinary Anthology. Manchester, England, Manchester University Press.
Reynolds, Kimberley (1998) 'Publishing practices and the practicalities of publishing', in Reynolds, Kimberley and Tucker, Nicholas (eds) Children's Book Publishing in Britain Since 1945. London, Scolar.

Sands-O’Connor, Karen (2001) 'Why are people different?: Multiracial families in picture books and the dialogue of difference', The Lion and the Unicorn 25, 3: 412-426.

Shyllon, Folarin (1992) 'The Black presence and experience in Britain: An analytical overview', in Jagdish S. Gundara and Ian Duffield (eds) Essays on the History of Blacks in Britain: From Roman Times to the Mid-Twentieth Century. Aldershot, England, Avebury, pp. 202-224.

Swindells, Robert (1997) Smash! London, Puffin.

White, Paul (1995) 'Geography, literature and migration', in R. King, J. Cornell and Paul White (eds) Writing Across Worlds: Literature and Migration. London, Routledge.

Young Writers (2003) 'Robert Swindells'. www. mystworld.com/youngwriter.

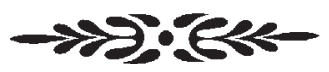

\section{BIOGRAPHICAL NOTE}

Karen Sands-O'Connor is an assistant professor at Buffalo State College in New York, USA. Although she has published on a wide variety of children's literature, from Louisa May Alcott's Little Women to late 20th century science fiction series, her critical focus has often been the interaction among ethnic minorities and the culture in which they live. This article is part of a larger project that will examine Britain's changing views about race, ethnicity and diversity as presented in children's literature over the last 300 years. 